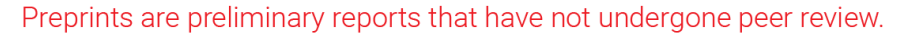 They should not be considered conclusive, used to inform clinical practice, or referenced by the media as validated information. \\ Offspring Development Conditioning (ODC): A Universal Trend in Evolution of Higher Organisms' Reproduction
}

\section{Qiang Fu}

Nanjing Institute of Geology and Palaeontology Chinese Academy of Sciences

Jianni Liu

Northwest University

Xin Wang ( $\nabla$ xinwang@nigpas.ac.cn )

Nanjing Institute of Geology and Palaeontology Chinese Academy of Sciences

\section{Research article}

Keywords: reproduction, evolution, oviparity, ovoviviparity, viviparity, animals, plants, angiosperms, Offspring Development Conditioning

Posted Date: June 30th, 2020

DOl: https://doi.org/10.21203/rs.3.rs-38147/v1

License: (a) (1) This work is licensed under a Creative Commons Attribution 4.0 International License. Read Full License 


\title{
Offspring Development Conditioning (ODC): A Universal Trend in Evolution of Higher Organisms' Reproduction
}

\author{
Qiang Fu ${ }^{1}$, Jianni $\mathrm{Liu}^{2}$, Xin Wang ${ }^{1,2}$
}

${ }^{1}$ State Key Laboratory of Palaeobiology and Stratigraphy, Nanjing Institute of Geology and Palaeontology and Center for Excellence in Life and Palaeoenvironment, Chinese Academy of Sciences, Nanjing 210008, China;

${ }^{2}$ Early Life Institute, State Key Laboratory of Continental Dynamics, Department of Geology, Northwest University, Xi'an 710069, China

*Correspondence author, XW email: xinwang@nigpas.ac.cn; JL email: liujianni@126.com 


\begin{abstract}
Background All organisms evolve, according to Darwin. The question is how? Is there any general pattern or trend in the organisms' evolution? These are rarely asked - and almost never answered questions. This situation makes the evolution frustrating and mysterious to many.

Results After surveying the reproductive modes in most animals and plants, we propose that all (at least most) of higher organisms demonstrate the similar trend underlying their reproductive evolution, namely, Offspring Development Conditioning (ODC). ODC benefit the organisms in two ways: one is enhanced physical protection, the other is secured nutrition supply.

Conclusions This pattern makes the origin and evolution of reproductive organs in both animals and plants rational and comprehensive. To the best of our knowledge, this pattern appears universal in higher organisms (including both plants and animals), although we encourage future colleagues to identify exceptions. We hope this will help frame the evolution of higher animals and plants, and make their evolution comprehensive to everyone.
\end{abstract}

Keywords: reproduction, evolution, oviparity, ovoviviparity, viviparity, animals, plants, angiosperms, Offspring Development Conditioning 


\section{Background}

Sardines spawn in water body of temperatures of $14-15^{\circ}$ off northern Spain in spring (Stratoudakis et al., 2007).

Some fishes give birth to their live young (Blackburn D.G., 2005, Xu et al., 2015, Helmstetter et al., 2016).

Kunmingella douvillei (from the Early Cambrian) carries ovules on its biramous appendages (Duan et al., 2014).

Some baby spiders kill and consume their mother, who has been carrying and feeding them (Salomon et al., 2015, Lubin, 2019).

A female praying mantis devours its partner during sex (Waleed, 2019).

Trichogramma lays its eggs inside the eggs of moths (Stouthamer, 1993).

Differentiation between megaspores and microspores started since the Devonian (Taylor et al., 2009).

Ovules remain attached to their mother plants since the late Devonian (Taylor et al., 2009).

Flowering plants have their ovules enclosed before pollination since the Mesozoic (Wang X., 2018).

Rhizophora apiculata give birth to their seedlings (Wilson andSaintilan, 2018).

Some parents pay for enrollment of their children in leading universities (Bacon, 2019).

Hundreds of penguins stand in freezing wind, warming their hatching eggs.

The above amazingly different behaviors of animals and plants attract much attention from various biologists, but it is rarely asked "Is there any common regularity underlying ALL these different behaviors?" Evolution! Yes, it is right. Evolution is a concept widely-accepted since the Darwin, and human beings have spent billions of dollars on the evolution of organisms on the Earth. However, evolution appears emanating and elusive to many.

\section{Results}

Based on a survey of all reproductive processes and modes in higher organisms, we recognize a general trend in the origin and evolution of reproductive organs in animals AND plants, namely, all higher organisms tend to increasingly condition the development of their offspring. We termed it as "Offspring Development Conditioning" (ODC).

\section{Discussion}

If life is taken as an evolvable set of coordinated interactions among organic molecules, then evolution can be seen as a process maintaining and modifying such regulated interaction networks through times. Maintaining the lineage is the primary and also ultimate goal for all organisms, and also the premise for the on-going of evolution. A chain breaks at its weakest link. Since maintaining lineages through time is implemented through continued repetition of sexual reproduction cycles (SRC)(Bai, 2015), and early stage in each individual's life cycle is the most vulnerable period in the SRC, therefore nurturing the babies and protecting them from harms are therefore the major challenges and tasks for all higher organisms. However, different higher organisms accomplish the same goal through different strategies (Angelini andGhiara, 1984, Wang X., 2018). We will go over the strategies of animals and plants, respectively.

Animals

All higher organisms are currently mainly categorized by, besides other characters, their 
reproductive modes in systematics. Among animals, several reproductive modes are recognized, namely, ovulipary, ovipary, ovo-carrying, ovovivipary, histotrophic vivipary, and hemotrophic vivipary (Table 1) (Angelini andGhiara, 1984). Considering these modes following the above order, which is also the order of their occurrence in their geological history, there is a common underlying trend, namely, that the developmental environment of the offspring becomes increasingly internalized and controlled (Table 1; Fig. 1). For example, the fertilization site is shifts from external (in water for fishes) (Fig. 2a) to internal (in the uterus for reptiles) (Fig. 2c). The hatching site of fertilized eggs shifts from ex vivo in fishes to the body surface of the mother in Kunmingella (Fig. 3b, Duan et al., 2014) and Waptia (Caron and Vannier, 2016), until certain length of time retention within mother body before birth of babies in some amphibians, some reptiles, and mammals (Lodé, 2012).

As one of the ways to implement ODC, offspring environment internalization (OEI) is also the mechanism by which reproductive organs in higher animals originated and evolved. During the process of OEI nurturing babies is increasingly enhanced, secured and extended, and the nurture source changes from egg alone (in fishes), its peers (oophagy, intra-uterine cannibalism in salamanders (Lodé, 2012)), a secretion of the oviducts (in insects and reptiles (Lodé, 2012)), to placenta-like structure or a true placenta (in mammals (Lodé, 2012)). In the meantime, the nurture bond between babies and mothers becomes increasingly physically reinforced and much extended in time. The net result of these coordinated changes is that mothers have gained increasingly tight control over the development of their babies, and babies become increasingly physically protected before birth and increasingly capable of surviving after birth. For example, baby rattlesnakes are born as live young fully loaded with fangs and venom at birth, and many mammals can stand and walk minutes after birth. Parent animals appear to play increasingly active roles in the life of their babies.

To cope with the various challenges of life and implement effective baby-protection, animals have developed various strategies and undergone several stages of adaptation, including passive adaptation, active environment selection, active environment conditioning. For example, fishes usually spawn in a water body. If the water body is congenial, their eggs can become fertilized and successfully develop into baby fishes. However, if the environment is not ideal, the eggs may not be fertilized or not develop at all. Under this scenario (passive adaptation), the eggs are passive and their fate is more due to chance. Avoiding such uncertainty, some fishes have developed a migratory habit as a strategy throughout the process of evolution. Migratory habits can guide fishes to water bodies of the right temperature for spawning at right time. Under this scenario (active environment selection), although the fate of eggs is still determined by water body, the fishes, relying on the habit carried on from their ancestors, are more active in choosing a suitable developmental environment for their babies.

A slightly more active selection for a suitable environment is ovule-carrying strategy adopted by some invertebrates (Fig. 3a), and this strategy can be dated at least back to the Early Cambrian (active environment conditioning) (Duan Yanhong et al., 2014, Caron andVannier, 2016). "Nothing is better than myself' may be the philosophy adopted by Kunmingella (Fig. 3b): by carrying their eggs on their bodies, these animals apparently had more liberty to choose a decent developmental environment congenial for their babies. Through ovo-vivipary (Fig. 3c) and histotrophic vivipary, such a trend culminates in hemotrophic vivipary, in which the fertilization takes place in vivo, the baby absorbs nutrients from the mother through a placenta and is not exposed to the external environment until birth. Compared to ovipary, vivipary with a higher degree of ODC brings many advantages including higher rates of speciation and greater species turnover through time, which triggered a burst of speciation and diversification (Fig. 1) (Pyron andBurbrink, 2014, Helmstetter et al., 2016). It is not surprising that 
vivipary has evolved independently at least 29 times in fishes (Wourms, 1981, Blackburn D.G., 2005, Blackburn Daniel G. andSidor, 2014), several times in anurans (Sandberger-Loua et al., 2017), several times in salamanders (Buckley, 2012), and six times in squamates (Wang Y. andEvans, 2011).

Although famous for their ovipary, not all snakes are oviparous, for example, rattlesnakes are ovoviviparous (Ryan, 2019). In birds, there is no vivipary, but this is compensated for by brooding by hatching and baby-care. By brooding, birds warm and protect their eggs by sitting on their eggs fairly continuously for prolonged periods. As rare exceptions, birds in several families do not incubate their own eggs but lay eggs in the nests of other taxa (brood parasitism). The cuckoo (Cuculus canoros, Cuculiformes) of Europe and cowbird (Molothrus ater, Passeriformes) of North America are well known obligatory parasites. Although they do not brood themselves, they have developed strategies advanced enough to cheat others to brood on their behalf and ensure the safety of their own babies (Geltsch et al., 2016). Needless to say, most mammals are viviparous. This at least partially contributes to the great diversity of mammals today (Fig. 1). As an exception among mammals, monotremes are the only living oviparous placentals (Eutheria) that, like marsupials, keep their larvae-like hatchings in a pouch and nurse them with milk.

Frequently, animals extend their prenatal offspring-caring beyond birth, sometimes by altruism. Spiders and many mammals nurture their babies with milk (Chen et al., 2018). Some spiders carry their babies and devote their bodies to nurture their babies (Salomon et al., 2015, Lubin, 2019). Sexual cannibalism in the praying mantis similarly involves consumption of the male to nourish the babies (Brown andBarry, 2016). Humans extend their parental care beyond nutritional supply and physical protection in the juveniles (Fig. 2d), including intellectual training (e.g. college education) and wealth transfer as a legacy for future generations (Bacon, 2019).

It can be said that, unlike taught in textbooks, there is no strict one-to-one correspondence between taxa and reproductive modes in animals (Fig. 1). Instead, different lineages of animals have adopted different spectra and combinations of reproductive strategies, and within each lineage the strategies involving enhanced conditioning of the development for their offspring were derived later and have given the animals more advantages in competition for survival against peers. Lower animal groups tend to have wider spectra and more alternatives in reproductive mode, while higher animal groups tend to be more limited and are restricted to relatively more advanced modes.

\section{Plants}

Many assume that animals are more advanced than plants, which usually do not move. This thinking is apparently erroneous. Surveying reproduction in plants, you will be surprised that plants demonstrate exactly the same evolutionary reproductive trend as animals do above (Figs. 4a-i). According to their reproductive modes, these plants can be categorized as spore plants (early land plants and ferns sensu lato) and seed plants (including gymnosperms and angiosperms). Early land plants and ferns sensu lato are/were dispersed as spores (Fig. 4a). Each spore, when dispersed, carries very limited nutrient from the mother plant, and its survival is largely due to chance, depending on its reaching a suitable environment, which allows the development of gametophytes, ensuing fertilization, and germination of the sporophyte for the next generation. If a spore is unlucky, then the limited nutrient from the mother plant is soon exhausted and sets an upper limit of the vitality of the spore and its derivative. Initially, all spores were of the same morphology, namely, there is little differentiation in spore dimensions, morphology and nutrition allocation in early land plants. However, differences emerged soon (in the Devonian) in various aspects in more derived heterosporous plants.

Among heterospores, a megaspore receives more nutrients and this ensures that the female 
gametophytes have enough nutrient supply while the microspore is allocated only limited basic amount of nutrition (Wang Xin andBai, 2019). Evolutionary history indicates that such differentiation apparently gives the plants more advantages, as the dominant plants seen in current ecosystems are heterosporous, and plants further extrapolate such a tendency to a later form, seed habit (Fig. 4b). Among fossils it is sometimes hard to distinguish seeds from megaspores morphologically. Yet it is easy to distinguish them in living plants; namely, a megaspore falls off from the mother plant when mature, while an ovule remains on its mother plant until it gives rise to a mature seed (Herr, 1995). The apparent advantage of a seed over a megaspore is that the seed maintains its nutrient bond with the mother plant until seed maturation. In addition, many gymnosperms can provide various additional protections for their seeds (Fig. 4c). Such enhanced nutritional bond and additional physical protection by mother plants is an evolutionary trend which has been followed since the origin of seeds (Figs. 4b-g).

This trend reached its greatest extent in angiosperms, which usually enclose their ovules before pollination (angio-ovuly) (Figs. 3d,f). Such an enclosure ensures the nutrient supply to the ovules, protects the vulnerable ovules from various harsh biotic and abiotic harms, benefits the dispersal of seeds by an additional (usually fleshy) surrounding layer, gives many advantages to angiosperms, which are the most diverse plant group in the current world. Continuing this trend, angio-ovuly is followed by angio-carpy (Figs. 4e, g) and vivipary (Fig. 4h). In angio-carpy, fruits that enclose seeds are further surrounded or enclosed by an extra layer of tissues (Figs. 3e, g). Such a phenomenon has been observed at least in the living Monimiaceae (Lorence, 1985, Staedler et al., 2007), Calycanthaceae (Staedler et al., 2007), Moraceae (Kvitvik, 1997), Solanaceae (Wilf et al., 2017), and also in some early fossil angiosperms (Chaoyangia, Callianthus) (Duan S., 1998, Wang X. andZheng, 2009, Wang X., 2018). Many people assume that vivipary is a feature unique to mammals, and they rarely know that angiosperms also have this feature. To date, nearly one hundred species of angiosperms (in 40 genera and 23 families) have been described as viviparous (Elmqvist andCox, 1996). Rhizophora is a typical mangrove tree. Unlike most plants, the seeds of Rhizophora germinate in vivo, namely, in fruits that are still attached to the mother plants (Fig. 4h). This means that the sporophytic seedlings rely on the mother plants (that usually nurture only their gametophytes) for their nutrient supply until the seedlings reach certain maturity.

Finally, the most animate strategy adopted by plants is proactive self-fertilization (PSF) in Orchidaceae. During PSF, the pollinarium is inserted into the receptive stigmatic cavity through the programed movement of its stipe (Liu et al., 2006) (Fig. 3i), thus culminating the ODC in plants. In this case, instead relying of external abiotic or biotic factors for pollination, the plant completes pollination through a series of self-driven movements of its own stamens. PSF makes the concerned orchids fully independent of otherwise indispensable pollinating agents during pollination and thus ensures the successful reproduction and continuation of lineage (Liu et al., 2006). Apparently, PSF gives the plant more freedom and control over the whole process of its reproduction.

\section{Conclusions}

ODC is a general evolutionary trend underlying reproduction in most higher animals and plants. First, fertilizing site is shifted from ex vivo in less advanced higher organisms to a more controlled in vivo site in more advanced higher organisms. Second, the developmental site of the embryos becomes increasingly in vivo within each lineage. Third, the nutritional bond between mothers and their offsprings is increasingly reinforced throughout the evolution, not only in prenatal stage but also in postnatal stage.

Fourth, the time during which the nutritional bond between mothers and their offspring becomes 
increasingly longer and stronger. Fifth, at least most lineages evolve comparable reproductive modes following the same trend in their own lineages, although each in a different way and in a different context, just like all rivers running from mountains into oceans in their own channels. So the evolution of most higher organisms (probably with exceptions of parasites) is destined to more enhanced Offspring Development Conditioning (ODC). One of the ways to implement ODC is internalizing the formerly external developmental site as a site within the organism's body, monitoring and controlling the developmental process of the offspring. This is how the reproductive organs (including flowers) originated.

\section{Methods}

Considering the great number of taxa involved in our study (including both animals and plants, fossil and extant), it is impossible for ourselves to investigate all of the taxa. Instead, to generalize a pattern of reproduction evolution in higher organisms, we had surveyed the reproductive modes currently documented across all major taxa of animals and plants. So no original or new data were generated during this research. We extracted and collected data about reproduction in all higher organisms from cited references. Partial data of some representative organisms (extant and fossil) shown in figures were collected by the authors during our research practice. All the information were mapped in phylogeny tree or tables. Analysis and generalization were performed based on these data.

\section{Abbreviations and Terms}

Angio-ovuly: Enclosure of ovules (precursors of seeds) before pollination.

Angio-carpy: Enclosure of fruits by additional tissues.

Angiosperm: A plant that, literally, has its seeds enclosed. Angio-ovuly ensures the affinity of a plant.

Brood parasitism: A type of parasitic organisms that rely on others to brood their young.

Endospory: Retaining spores within sporangia after their maturation.

Gymnosperm: A plant that, literally, has its seeds exposed to the exterior space.

Hemotrophic vivipary: Fertilization and embryogenesis occur in the female genital tract and find their nutriments from the maternal bloodstream through the placenta.

Heterospory: Occurrence of two different spores in a single individual.

Histotrophic vivipary : Giving birth to live offspring such that the zygotes develop in the female's oviducts, but receive their nutriments from the decomposition of maternal tissue and leakage of maternal blood.

Matriphagy: Babies are fed with the body of their own mother.

Megaspore: Relatively larger of two types of spores, usually develops into a female gametophyte.

Migratory habit: Regular seasonal movement of animals across regions to ensure the maintenance of the fauna.

Obligatory parasites: Organisms that are dependent upon a host for survival.

ODC: offspring development conditioning.

OEI: offspring environment internalization.

Oophagy (egg-eating): A means of nutrition in which some embryos in the mother's uterus develop at the expense of their 'potential siblings'.

Ovipary: A reproductive strategy with a lower number of larger eggs, generally with internal fertilization, direct development, and frequent parental care.

Ovovivipary: A method of reproduction in which young develop from eggs retained within the 
mother's body, but separated from it by the egg membranes.

Ovule-carrying: A breeding strategy in which ovules are carried on the body surface of animals during incubation.

Ovulipary: A reproductive strategy with a great number of smaller eggs, with external fertilization and a larval stage.

Parasitic hatching: Some brood parasites rely on others to hatch their young.

Parental care: A parent invests time and/or energy in feeding and protecting its offspring.

Proactive Self-fertilization: Fertilization completed by self-driven movement of the stamen/pollinarium stipe, during which the pollinarium is inserted into the receptive stigmatic cavity.

Seed: A plant organ derived from an ovule, containing an embryo.

Sexual cannibalism: A female cannibalizing her mate during or after copulation.

Spore: A small single-celled propagule capable of giving rise to a gametophyte.

Vivipary: Giving birth to live offspring that develop within the mother's body, or producing seedlings.

\section{Declarations}

Availability of data and materials This paper covers all higher organisms, which include too many taxa or materials to fit in the space of this paper. For further information, please refer to the cited references.

Competing interests We declare no competing interests.

Funding This research is supported by the Strategic Priority Research Program (B) of Chinese Academy of Sciences (Grant No. XDB26000000), National Basic Research Program of China (973 Program 2012CB821901), and National Natural Science Foundation of China (41688103, 91514302, 41572046).

\section{Authors' contributions}

QF is a research professor at the Nanjing Institute of Geology and Palaeontology, major in evolution of plants. PhD of the Nanjing Institute of Geology and Palaeontology, Chinese Academy of Sciences , 2006; Master of the South China Botanical Garden, Chinese Academy of Sciences, 2003; Bachelor of the Yantai Normal University, 2000.

$\mathrm{JL}$ is a professor at the Northwest University, major in Cambrain explosion. $\mathrm{PhD}$ of the Northwest University, 2006; Master of the Northwest University, 2003; Bachelor of the Northwest University, 2001.

XW is a research professor at the Nanjing Institute of Geology and Palaeontology, Chinese Academy of Sciences, major in evolution of plants, focusing on origin of angiosperms. $\mathrm{PhD}$ of the University of Florida, 2004; Master of the Institute of Botany, Chinese Academy of Sciences, 1993; Bachelor of the Peking University, 1990.

$\mathrm{XW}$ initiated the project; XW, QF and JL collected data, performed analysis, wrote and finalized the manuscript. 
Acknowledgements We appreciate Dr. Jason Dunlop (Museum für Naturkunde, Leibniz Institute for Research on Evolution and Biodiversity at the Humboldt University Berlin) for help with the English.

\section{References}

Angelini F, Ghiara G. Reproductive modes and strategies in vertebrate evolution. Ital J Zool. 1984; 51:121-203.

Bacon J. Stanford kicks out student linked to largest-ever college admissions scandal. USA Today (2019). Accessed on 24 May, 2019.

Bai SN. The concept of the sexual reproduction cycle and its evolutionary significance. Sci Sin Vit. 2015; 45:811-19.

Blackburn DG. Evolutionary origins of viviparity in fishes. In: Grier HJ, Uribe MC, editors. Viviparous fishes. (Homestead, Florida: New Life Publications) 2005. p. 287-301.

Blackburn DG, Sidor CA. Evolution of viviparous reproduction in Paleozoic and Mesozoic reptiles. Intl J Dev Biol. 2014; 58:935-48.

Brown WD, Barry KL. Sexual cannibalism increases male material investment in offspring: quantifying terminal reproductive effort in a praying mantis. Proc Roy Soc B. 2016; 283:20160656.

Buckley D. Evolution of viviparity in Salamanders (Amphibia, Caudata). Wiley Online Library: Encyclopedia of Life Sciences. 2012. https://doi.org/: 10.1002/9780470015902.a0022851.

Caron J-B, Vannier J. Waptia and the diversification of brood care in early arthropods. Curr Biol. 2016; 26:69-74.

Chen Z, et al. Prolonged milk provisioning in a jumping spider. Science 2018; 362:1052-55.

Duan S. The oldest angiosperm ---- a tricarpous female reproductive fossil from western Liaoning Province, NE China. Sci China D. 1998; 41:14-20.

Duan Y, et al. Reproductive strategy of the bradoriid arthropod Kunmingella douvillei from the Lower Cambrian Chengjiang Lagerstätte, South China. Gond Res. 2014; 25 983-90.

Elmqvist T, Cox PA. The evolution of vivipary in flowering plants. Oikos 1996; 77:3-9.

Geltsch N, Ban M, Hauber ME, Moskat C. When should common cuckoos Cuculus canorus lay their eggs in host nests? Bird Study 2016; 63:46-51.

Helmstetter AJ, Papadopulos AST, Igea J, Dooren TJMV, Leroi AM, Savolainen V. Viviparity stimulates diversification in an order of fish. Nat Comm. 2016; 7:11271.

Herr JMJ. The origin of the ovule. Amer J Bot. 1995; 82:547-64.

Kvitvik TA. Ficus lacunata (Moraceae), a new species from pluvial montane forest of northwest Ecuador. Brittonia 1997; 49:270-73.

Liu K-W, Liu Z-J, Huang L, Li L-Q, Chen L-J, Tang G-D. Self-fertilization strategy in an orchid. Nature 2006; 441:945-46.

Lodé T. Oviparity or viviparity? That is the question.... Repr Biol. 2012; 12:259-64.

Lorence DH. A monograph of the Monimiaceae (Laurales) in the Malagasy region (Southwest Indian Ocean). Ann Miss Bot Gard. 1985; 72:1-165.

Lubin Y. Arachnid matriphagy: These spider mothers literally die for their young. Entomology Today. 2015. Accessed on May 24, 2019.

Pyron RA, Burbrink FT. Early origin of viviparity and multiple reversions to oviparity in squamate reptiles. Ecol Lett. 2014; 17:13-21.

Ryan T. How rattlesnakes hatch. https://animals.mom.me/rattlesnakes-hatch-2100.html. Accessed on May 28, 
2019.

Salomon M, Aflalo ED, Coll M, Lubin Y. Dramatic histological changes preceding suicidal maternal care in the subsocial spider Stegodyphus lineatus (Araneae: Eresidae). J Arach. 2015; 43:77-85.

Sandberger-Loua L, Müller H, Mark-Oliver Rödel. A review of the reproductive biology of the only known matrotrophic viviparous anuran, the West African Nimba toad, Nimbaphrynoides occidentalis. Zoosyst Evol. 2017; 93 105-33.

Staedler YM, Weston PH, Endress PK. Floral phyllotaxis and floral architecture in Calycanthaceae (Laurales). Intl J Plant Sci. 2007; 168:285-306.

Stouthamer R. The use of sexual versus asexual wasps in biological control. Biocontrol 1993; 38:3-6.

Stratoudakis Y, et al. Sardine (Sardina pilchardus) spawning seasonality in European waters of the northeast Atlantic. Mar Biol. 2007; 152:201-12.

Taylor TN, Taylor EL, Krings M. Paleobotany: the biology and evolution of fossil plants. 2nd ed. Amsterdam: Elsevier; 2009.

Waleed. Why does the female praying mantis eat the male? - Cannibalism. https://prayingmantis.org/why-does-the-female-praying-mantis-eat-the-male/. Accessed on May 24, 2019.

Wang X. The dawn angiosperms. 2nd ed. Cham, Switzerland: Springer; 2018.

Wang X, Bai S-N. Key innovations in transition from homospory to heterospory. Plant Sign Behav. 2019; $14: 6$.

Wang X, Zheng S. The earliest normal flower from Liaoning Province, China. J Integr Plant Biol. 2009; 51:800-11.

Wang Y, Evans SE. A gravid lizard from the Cretaceous of China and the early history of squamate viviparity. Naturwiss. 2011; 98:739-43.

Wilf P, Carvalho MR, Gandolfo MA, Cúneo NR. Eocene lantern fruits from Gondwanan Patagonia and the early origins of Solanaceae. Science 2017; 355:71-75.

Wilson NC, Saintilan N. Reproduction of the mangrove species Rhizophora stylosa Griff. at its southern latitudinal limit. Aqu Bot. 2018; 151:30-37.

Wourms JP. Viviparity: the maternal-fetal relationship in fishes. Amer Zool. 1981; 21:473-515.

Xu G-H, Zhao L-J, Shen C-C. A Middle Triassic thoracopterid from China highlights the evolutionary origin of overwater gliding in early ray-finned fishes. Biol Lett. 2015; 11:20140960. 


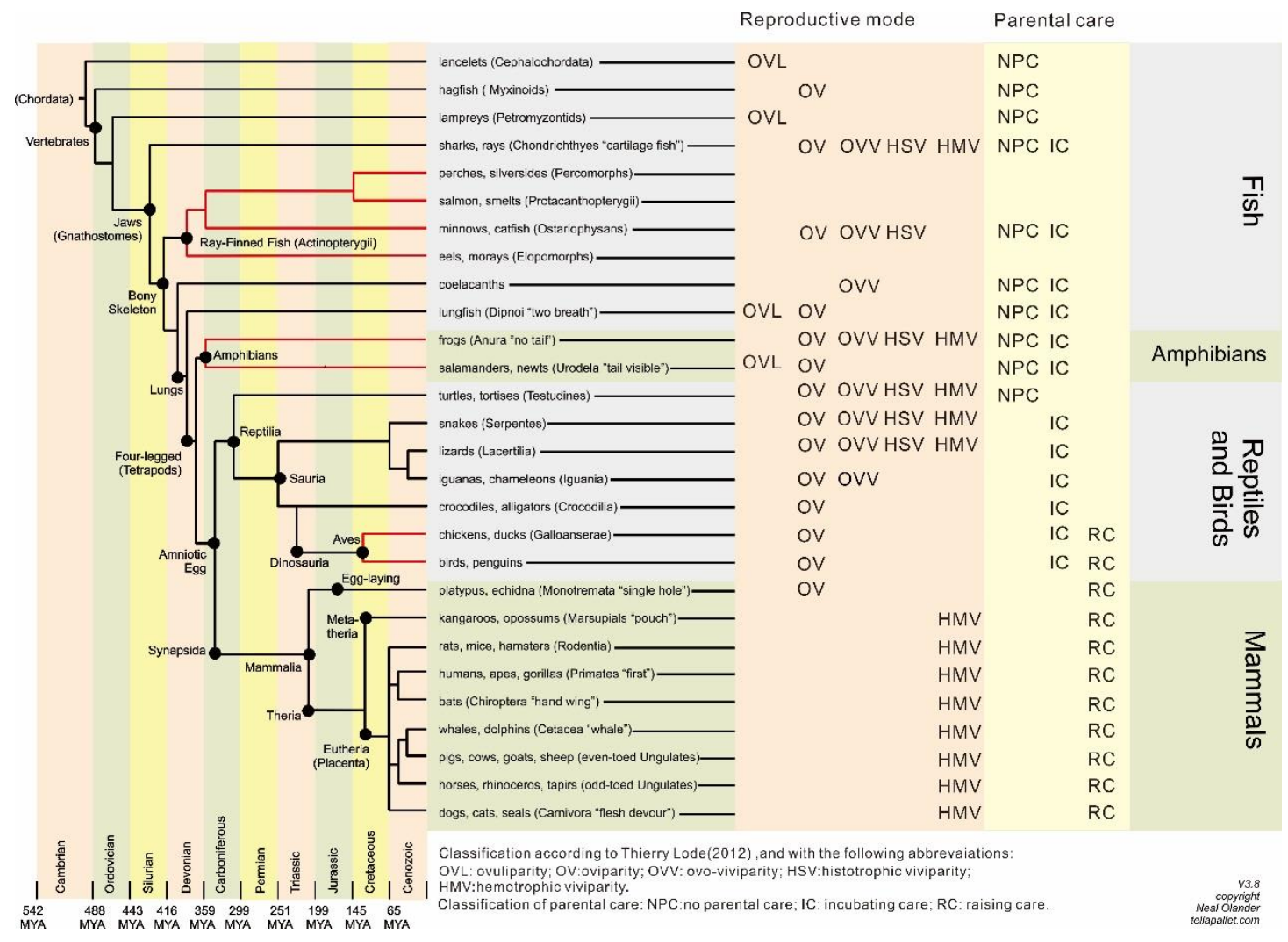

Fig. 1 Reproductive modes and phylogenetic dendrogram in Vertebrates 

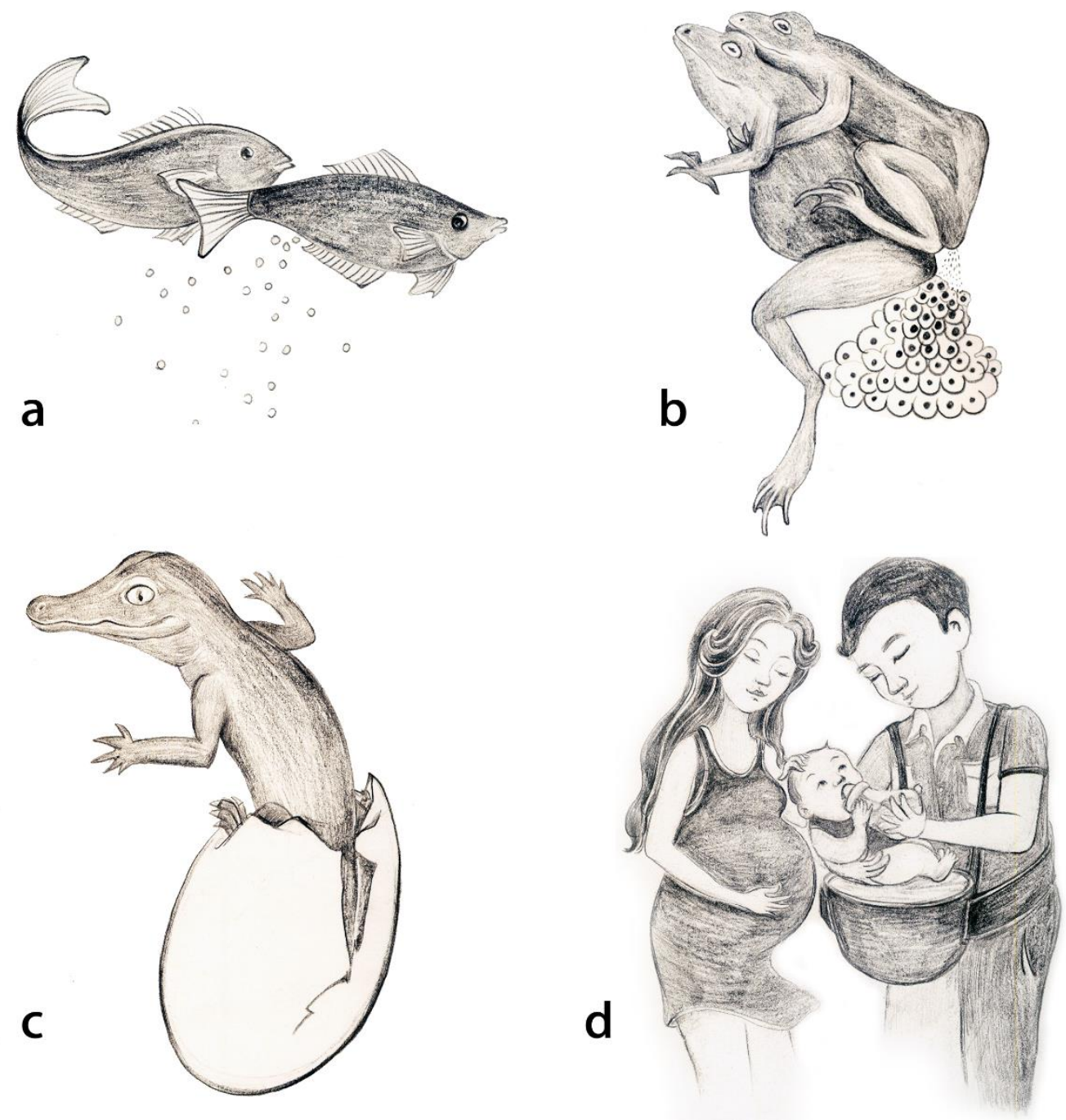

Fig. 2 Diversified reproductive modes in vertebrates. a. Ovulipary in fishes. b. Ovipary in frogs. c. Ovipary in reptiles. d. Vivipary in mammals (human beings). 

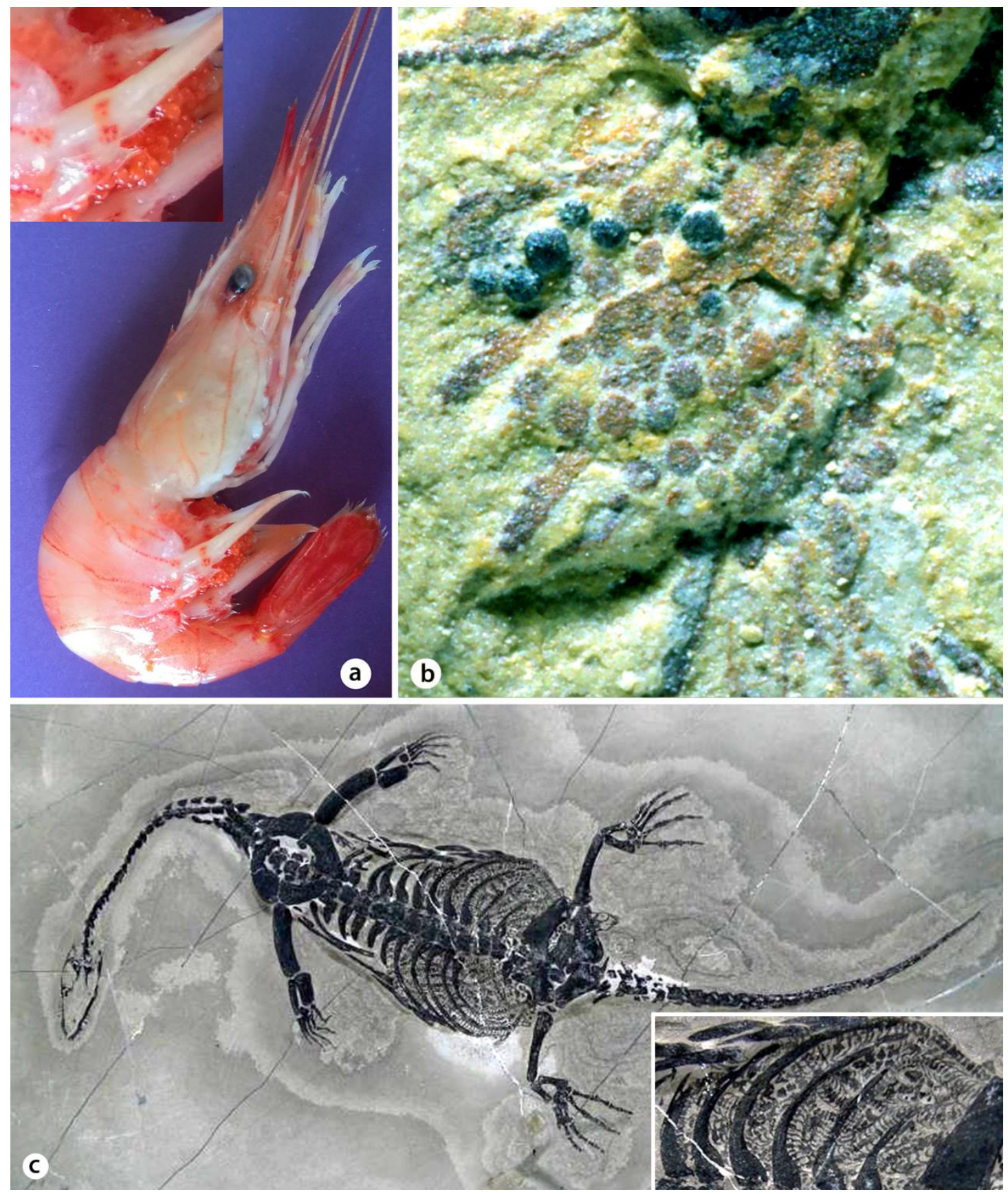

Fig. 3 Ovule-carrying and ovovivipary. a. Extant shrimp carrying ovules on its body surface. The inset shows the ovules on the appendages. b. Kunmingella (the Early Cambrian) carrying ovules on its appendages. c. Ovoviviparous marine reptile Keichousaurus with multiple youngs in its abdominal cavity. Inset shows detailed view of youngs inside mother's body (Reproduced from The Triassic Park with courtesy and permission from Pang Guangfan, Jin Renyi and Fu Xiaoping). 

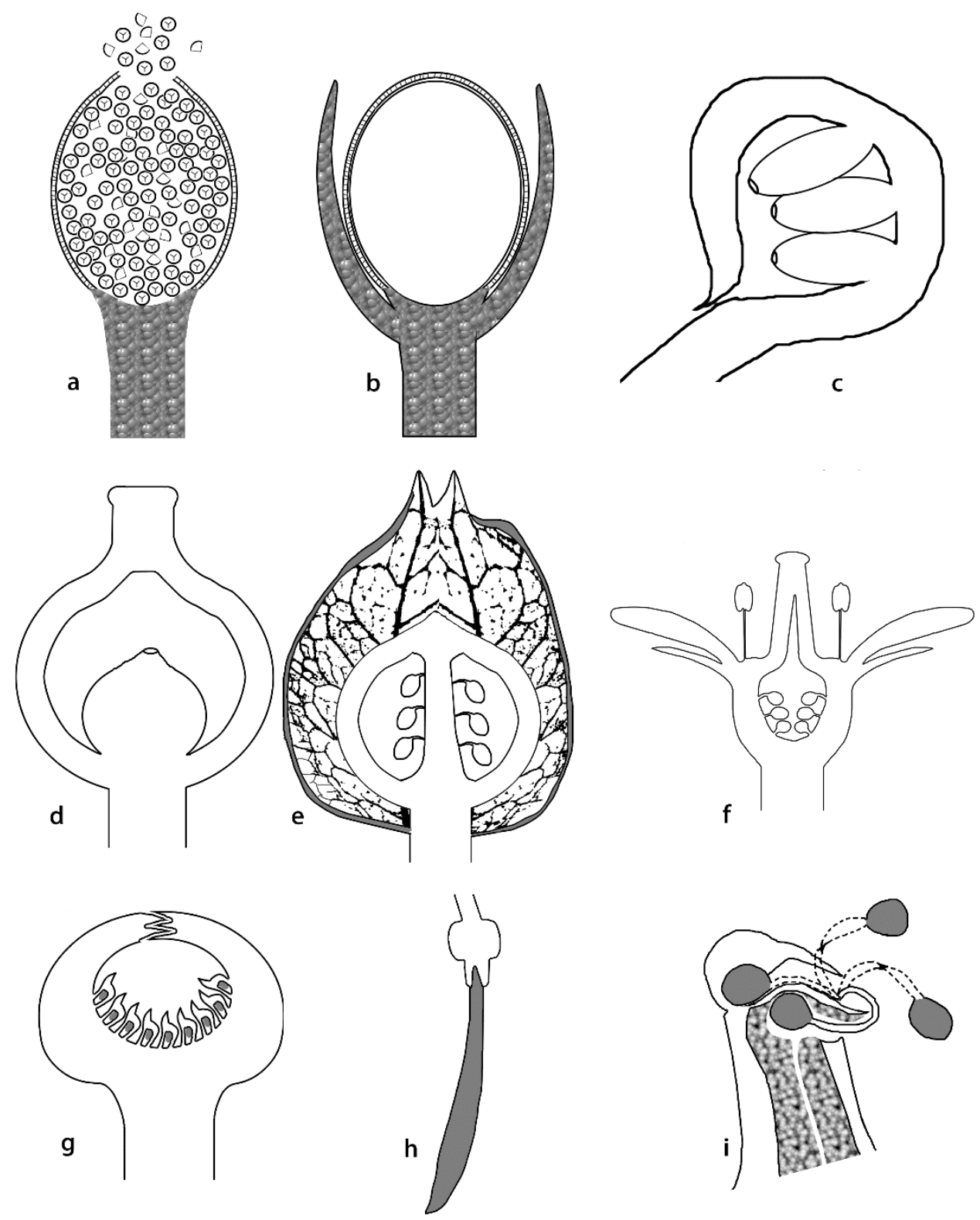

Fig. 4 Diverse reproductive modes in vascular plants. a. Spores dispersed from a sporangium in a spore plant. b. Ovule with protection from the integument. c. Ovules/seeds protected by cupule in Caytonia. d. A basal ovule protected by ovary in an angiosperm. e. A Physalis fruit with seeds inside and a protective layer around. f. Ovules protected by an inferior ovary in an angiosperm. g. Fruits inside and protected by hypanthodium. h. Sprout of Rhizophora on its mother plant. i. Proactive self-fertilization in Holcoglossum (Orchidaceae). 


\begin{tabular}{|c|c|c|c|c|c|c|c|}
\hline & $\begin{array}{l}\text { Fertilizati } \\
\text { on site }\end{array}$ & $\begin{array}{l}\text { Eggs } \\
\text { hatching } \\
\text { site }\end{array}$ & $\begin{array}{l}\text { Nutritional } \\
\text { supply }\end{array}$ & $\begin{array}{l}\text { Fecundit } \\
\mathrm{y}\end{array}$ & $\begin{array}{l}\text { Larvae } \\
\text { survival } \\
\text { rates }\end{array}$ & $\begin{array}{l}\text { Parental } \\
\text { care }\end{array}$ & Examples \\
\hline Ovuliparity & External & External & $\begin{array}{l}\text { Yolk } \\
\text { (Lecithotrophy) }\end{array}$ & Very high & Very low & No & $\begin{array}{l}\text { Teleostei: } \text { most of marine } \\
\text { forms with pelagic floating } \\
\text { eggs } \\
\text { Amphibia: } \text { many Anura } \\
\text { Cyclostomata: } \\
\text { Petromyzontoidea }\end{array}$ \\
\hline $\begin{array}{l}\text { Oviparity } \\
\text { with } \\
\text { aquatic egg }\end{array}$ & $\begin{array}{l}\text { External, } \\
\text { internal }\end{array}$ & External & $\begin{array}{l}\text { Yolk } \\
\text { (Lecithotrophy) }\end{array}$ & Moderate & Moderate & Frequent & $\begin{array}{l}\text { Chondrichthyes: many } \\
\text { Elasmobranchii } \\
\text { Teleostei: most fresh-water } \\
\text { forms with demersal eggs } \\
\text { Cyclostomata: Myxinoidei } \\
\text { Amphibia: many Urodela and } \\
\text { Apoda }\end{array}$ \\
\hline $\begin{array}{l}\text { Oviparity } \\
\text { with } \\
\text { terrestrial } \\
\text { amniotic } \\
\text { egg }\end{array}$ & Internal & External & $\begin{array}{l}\text { Yolk } \\
\text { (Lecithotrophy) }\end{array}$ & Low & High & $\begin{array}{l}\text { Frequent, } \\
\text { sometimes } \\
\text { intensive }\end{array}$ & $\begin{array}{l}\text { Reptilia } \\
\text { Aves }\end{array}$ \\
\hline $\begin{array}{l}\text { Aplacental } \\
\text { viviparity } \\
\text { (ovovivipar } \\
\text { ity) }\end{array}$ & Internal & Internal & $\begin{array}{l}\text { Yolk } \\
\text { (Lecithotrophy) } \\
\text { or reproductive } \\
\text { tract (uterine or } \\
\text { ovarian } \\
\text { secretions and } \\
\text { sibling yolks) }\end{array}$ & Moderate & Moderate & $\begin{array}{l}\text { Frequent } \\
\text { (lactation in } \\
\text { Prototheria) }\end{array}$ & $\begin{array}{l}\text { Chondrichthyes: many } \\
\text { Elasmobranchii } \\
\text { Amphibia: several Apoda; one } \\
\text { Anuran } \\
\text { Reptilia: some Squamata } \\
\text { Mammalia: Prototheria }\end{array}$ \\
\hline $\begin{array}{l}\text { Placental } \\
\text { viviparity } \\
\text { (histotrophi } \\
\text { c) }\end{array}$ & Internal & Internal & $\begin{array}{l}\text { Mother } \\
\text { (Matrotrophy) }\end{array}$ & Low & High & Frequent & $\begin{array}{l}\text { Chondrichthycs: } \\
\text { Elasmobranchii, including } \\
\text { Rhizoprionodon terraenovae } \\
\text { and Carcharhinus plumbeus } \\
\text { Reptilia: (several Squamata, } \\
\text { e.g. Mabuya heathi) }\end{array}$ \\
\hline $\begin{array}{l}\text { Placental } \\
\text { viviparity } \\
\text { (histotrophi } \\
\text { c } \\
\text { versus } \\
\text { hemotrophi } \\
\text { c) }\end{array}$ & Internal & Internal & $\begin{array}{l}\text { Mother } \\
\text { (Matrotrophy) }\end{array}$ & $\begin{array}{l}\text { Very low } \\
\text { (with } \\
\text { exception } \\
\text { s) }\end{array}$ & High & $\begin{array}{l}\text { Parental } \\
\text { care, with } \\
\text { lactation }\end{array}$ & $\begin{array}{l}\text { Mammalia: Metatheria and } \\
\text { Eutheria }\end{array}$ \\
\hline
\end{tabular}

Table 1. Main characteristics of various reproductive modes in Vertebrates. Data derived mainly from Angelini and Ghiara (1984). 


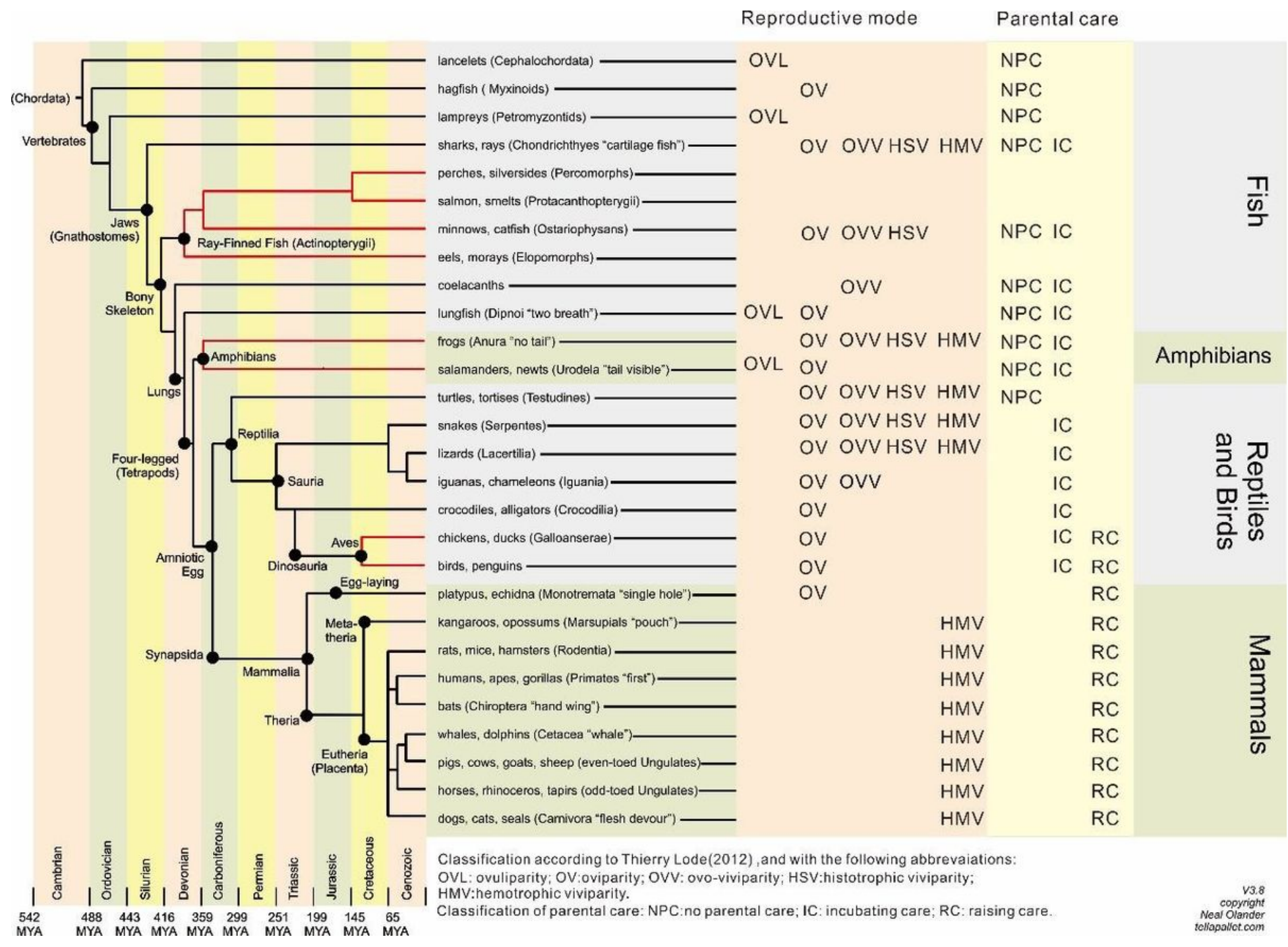

\section{Figure 1}

Reproductive modes and phylogenetic dendrogram in Vertebrates 

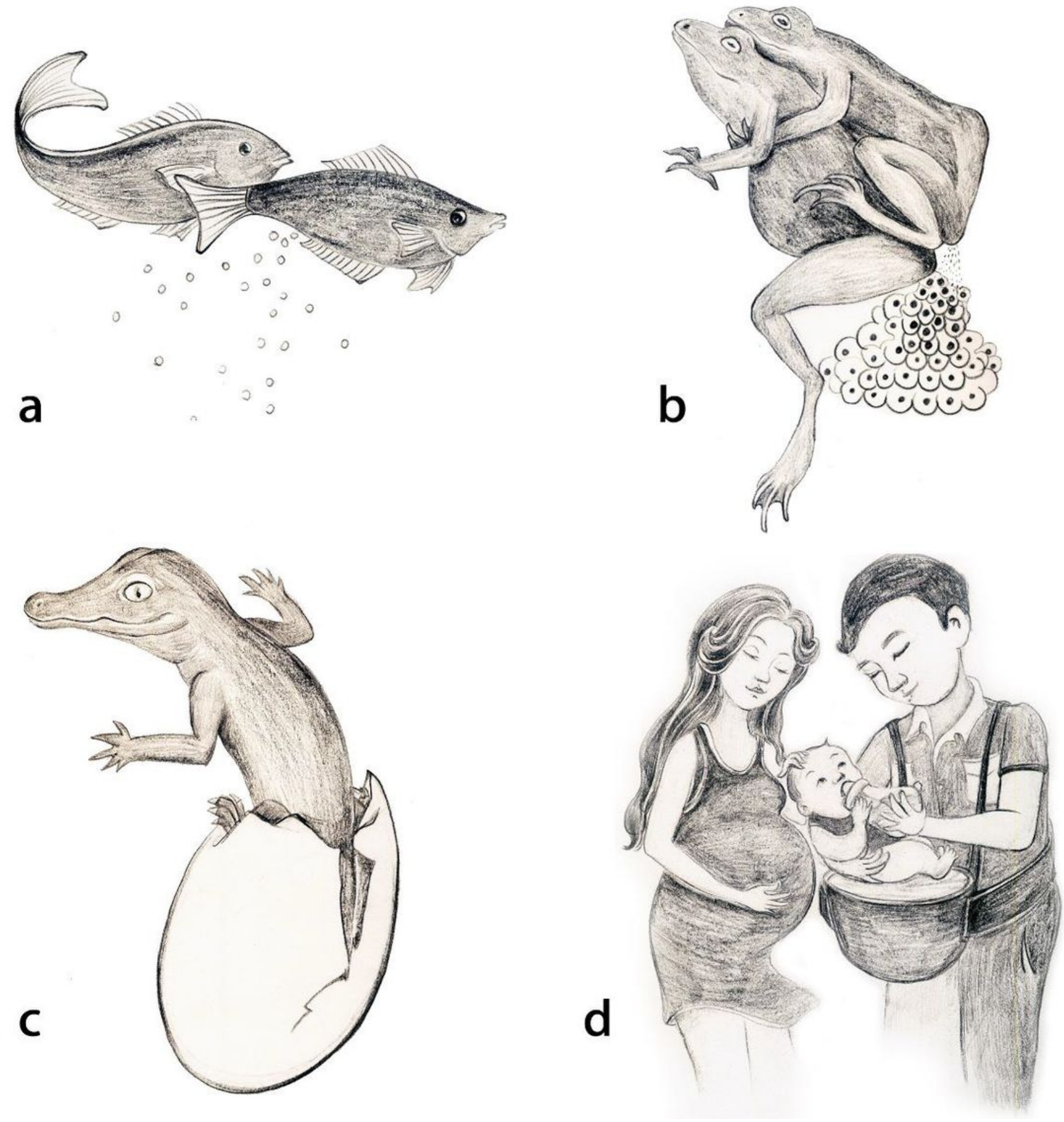

Figure 2

Diversified reproductive modes in vertebrates. a . Ovulipary in fishes. b. Ovipary in frogs. c. Ovipary in reptiles. $d$. Vivipary in mammals (human beings). 

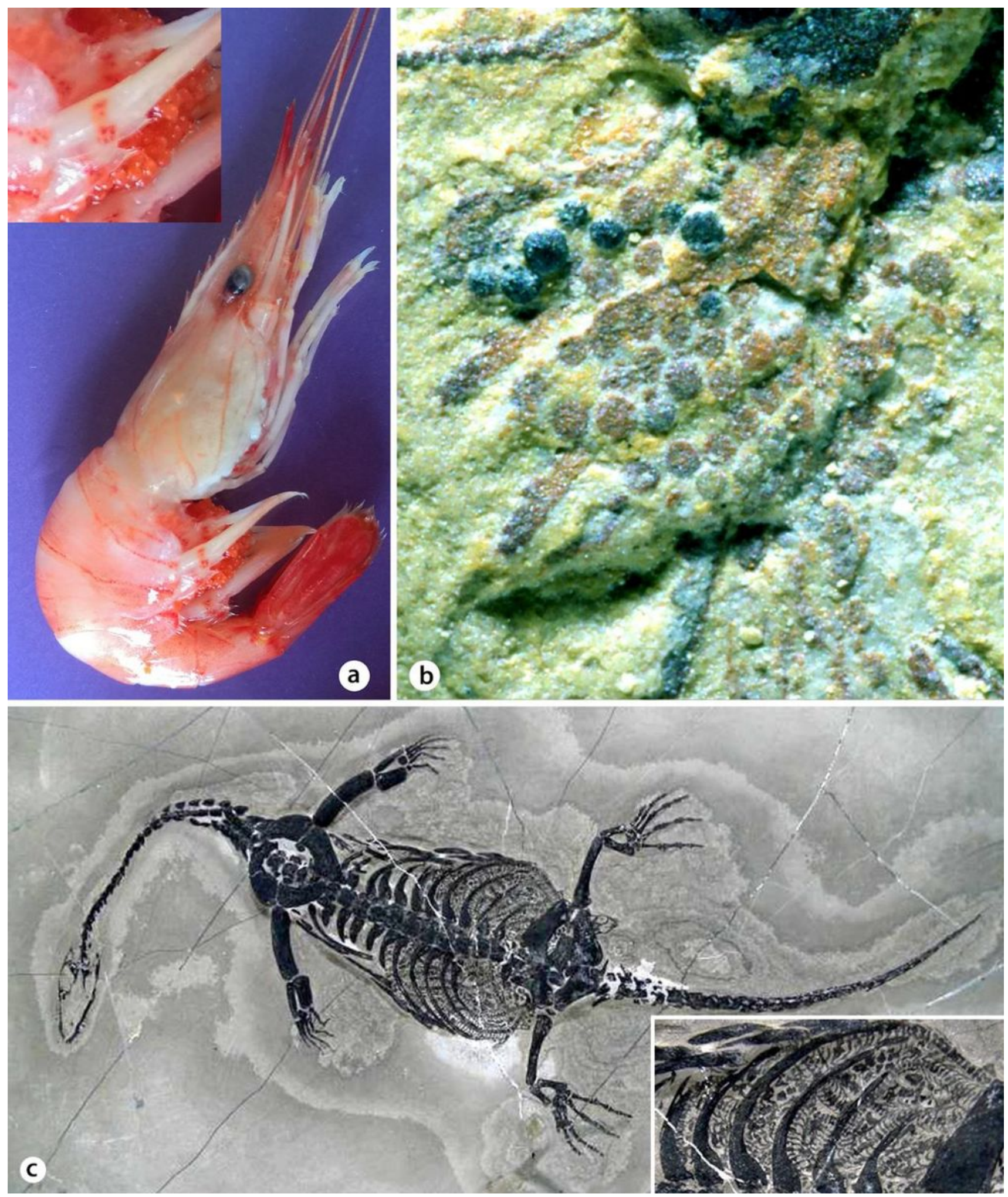

\section{Figure 3}

Ovule carrying and ovovivipary. a . Extant shrimp carrying ovules on its body surface. The inset shows the ovules on the appendages. b. Kunmingella (the Early Cambrian) carrying ovules on its appendages. $c$. Ovoviviparous marine reptile Keichousaurus with multiple youngs in i ts abdominal cavity. Inset shows detailed view of youngs inside mother's body (Re pr oduced from The Triassic Park with courtesy and permission from Pang Guangfan, Jin Renyi and Fu Xiaoping). 

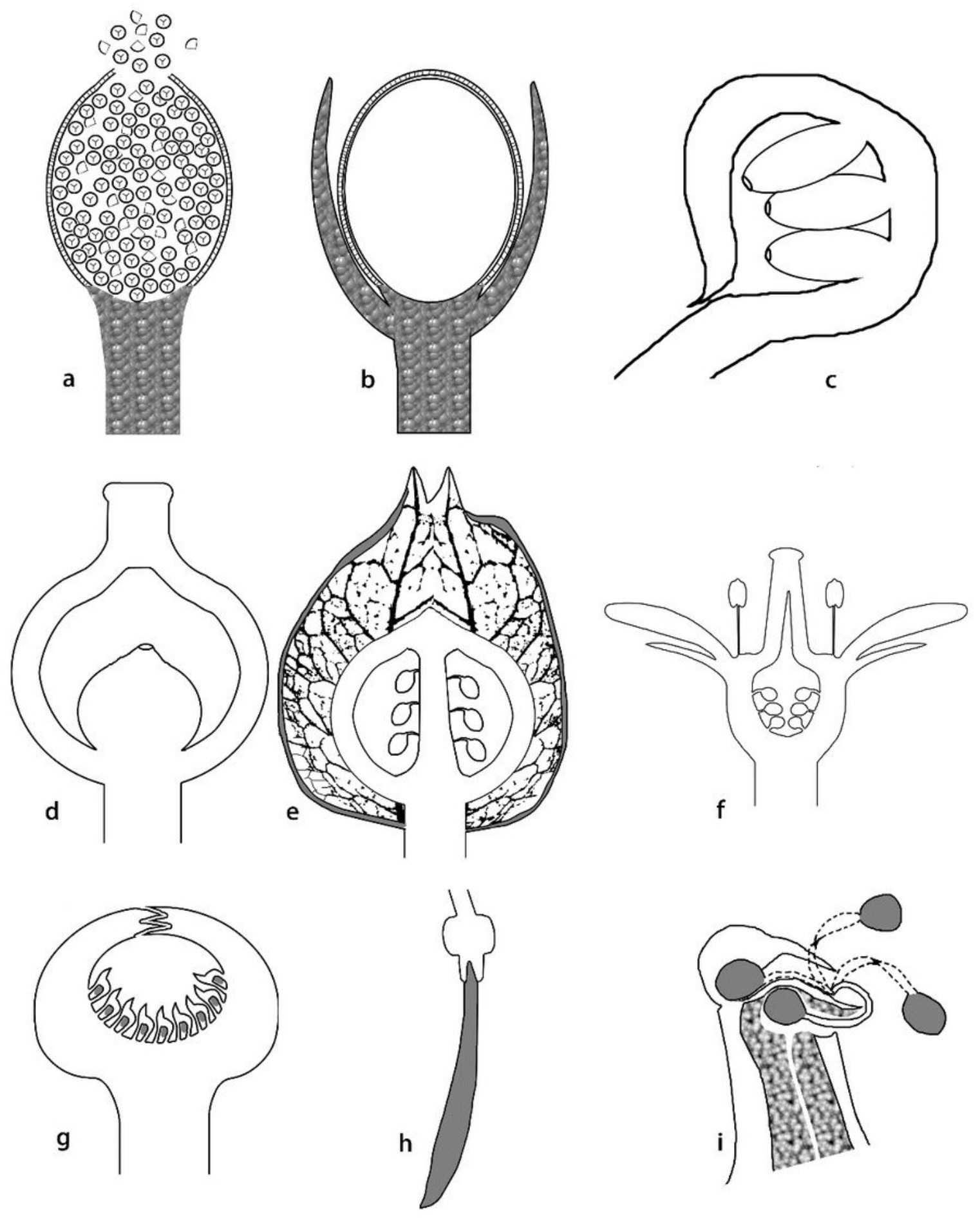

\section{Figure 4}

Diverse reproductive modes in vascular plants. a . Spores dispersed from a sporangium in a spore plant. b. Ovule with protection from the integument. c . Ovules/seeds protected by cupule in Caytonia . d . A basal ovule protected by ovary in an angiosperm. e. A Physalis fruit with seeds inside and a protecti ve layer around. $f$. Ovules protected by an inferior ovary in an angiosperm. g. Fruits inside and protected by 
hypanthodium. h. Sprout of Rhizophora on its mother plant. i. Proactive self fertilization in Holcoglossum (Orchidaceae). 